\title{
Role of S100A3 in human hepatocellular carcinoma and the anticancer effect of sodium cantharidinate
}

\author{
RAN TAO ${ }^{1,2^{*}}$, ZHONG-FENG WANG ${ }^{3 *}$, WEI QIU ${ }^{4}$, YU-FANG HE ${ }^{5}$, \\ WEI-QUN YAN ${ }^{2}$, WEN-YI SUN ${ }^{2}$ and HAI-JUN LI ${ }^{1}$ \\ ${ }^{1}$ Institute of Translational Medicine, The First Hospital of Jilin University; \\ ${ }^{2}$ Department of Clinical Pharmacy and Pharmaceutical Management, School of Pharmaceutical Sciences, Jilin \\ University; Departments of ${ }^{3}$ Hepatology and ${ }^{4}$ Surgery, The First Hospital of Jilin University, Changchun, Jilin 130021; \\ ${ }^{5}$ Institute of Phytochemistry, Jilin Academy of Chinese Medicine Sciences, Changchun, Jilin 130012, P.R. China
}

Received January 31, 2016; Accepted November 15, 2016

DOI: $10.3892 /$ etm.2017.4294

\begin{abstract}
The fifth most common cancer worldwide is hepatocellular carcinoma (HCC), which has an annual mortality rate of $\sim 800,000$. Although surgical procedures for HCC, such as hepatic resection and liver transplantation, have progressed and the outcomes of patients have improved, HCC is still characterized by frequent recurrence, even after liver transplantation. In the present study the expression of the protein coding gene, S100 calcium binding protein A3 (S100A3), was observed in $62 \mathrm{HCC}$ tissues and tumor-surrounding tissues. The present study indicated that S100A3 activation was involved in tumorigenesis and tumor aggressiveness. The protein and mRNA expression levels of S100A3 in the human HCC cell line (HepG2) were investigated using western blotting and reverse transcription-quantitative polymerase chain reaction analysis, respectively. The function of sodium cantharidinate in inducing HCC cell apoptosis was also investigated. Sodium cantharidinate inhibited the protein and gene expression of S100A3 in HepG2 cells in vitro. These data suggested that S100A3 has an important role in human HCC. The present study indicates that the functional properties of sodium cantharidinate are promising for the development of
\end{abstract}

Correspondence to: Mr. Hai-Jun Li, Institute of Translational Medicine, The First Hospital of Jilin University, 71 Xinmin Street, Changchun, Jilin 130021, P.R. China

E-mail: hjli2012@jlu.edu.cn

Dr Wen-Yi Sun, Department of Clinical Pharmacy and Pharmaceutical Management, School of Pharmaceutical Sciences, Jilin University, 1163 Xinmin Street, Changchun, Jilin 130021, P.R. China

E-mail: sunwy1973@163.com

*Contributed equally

Key words: S100 calcium binding protein A3, hepatocellular carcinoma, sodium cantharidinate a novel drug that may control the expression of S100A3 and improve the treatment of human $\mathrm{HCC}$ in the near future.

\section{Introduction}

Due to its incidence, hepatocellular carcinoma (HCC) is becoming the most common primary liver malignancy and is a leading cause of cancer-related mortality worldwide, with a mortality rate of $\sim 800,000$ per year (1). Surgical procedures for HCC have recently progressed with respect to hepatic resection and liver transplantation. However, limitations in treatment are evident in the frequency of recurrence observed, even after liver transplantation (2-5). There is, therefore, an urgency to develop novel approaches for HCC prevention and treatment. At present, chemotherapy is also a focus for tumor treatment (6). The molecular targeting agent, sorafenib, is reported to improve survival rates and the outcomes of patients with unresectable or early stage $\mathrm{HCC}(7,8)$. Although other target agents are under investigation, sorafenib remains the only approved molecular targeted treatment for advanced HCC. Trials comparing novel agents in combination with sorafenib are ongoing. Evaluations of combined treatment with systemic targeted therapies and local therapy are undergoing investigation to further improve the outcomes of patient with HCC (9-11).

The S100 protein family has a wide range of biological functions that are associated with the regulation of cell proliferation, differentiation, apoptosis, $\mathrm{Ca}^{2+}$ homeostasis, energy metabolism, inflammation and migration/invasion. These processes involve interactions with multiple target proteins, including enzymes, cytoskeletal subunits, receptors, transcription factors and nucleic acids. The matricellular protein, S100A3, is expressed in various tissues and cell types (12-14). S100A3 protein is encoded by the S100A3 gene and contains two EF-hand calcium-binding motifs in humans (15-17). These motifs are connected by 10-12 residues, which form a critical 'hinge' region (loop 2) that is involved in target interactions. In the absence of a target, the majority of S100 proteins exhibit low $\mathrm{Ca}^{2+}$-binding affinity; however, when a target is bound, a 5- to 300-fold increase in $\mathrm{Ca}^{2+}$-binding affinity occurs (18-20).

Over the last decade, the importance of S100A3 as a biomarker for tumor progression has been recognized, although 
it is unclear whether S100A3 is important in HCC and whether it is possible to inhibit S100A3 with drug treatment. During this period, the treatment options for HCC have expanded to include additional chemotherapeutic agents and targeted therapies $(21,22)$. In recent years, traditional Chinese medicine (TCM), or its extractions, have had a positive role in the treatment of cancer $(23,24)$. However, it has not yet been elucidated whether TCM is able to inhibit the expression of S100A3 and prevent the symptoms of HCC. Sodium cantharidinate has been used in TCM (25-27). Previous studies have indicated that sodium cantharidinate may induce cell cycle arrest and trigger apoptosis in various types of tumor cells (28-33).

The present study investigated whether S100A3 is important in HCC and whether sodium cantharidinate may be used to inhibit the expression of S100A3. The protein and mRNA expression levels of S100A3 in the human HCC cell line (HepG2) were investigated using western blotting and reverse transcription-quantitative polymerase chain reaction analysis, respectively. The function of sodium cantharidinate in inducing HCC cell apoptosis was also investigated. This research may provide novel targets for the treatment of $\mathrm{HCC}$ and thus further improve the outcomes of patient with HCC.

\section{Materials and methods}

Reagents. Sodium cantharidinate (C7632) was purchased from Meryer (Shanghai, China); MTT (4890-025) and RNase (HZB0210) were purchased from Sigma-Aldrich (Merck Millipore, Darmstadt, Germany). Propidium iodide (PI) and an Annexin V-fluorescein isothiocyanate (FITC) Apoptosis Detection kit were purchased from BD Biosciences (556547; San Jose, CA, USA). Dulbecco's modified Eagle medium (DMEM; 10-013), trypsin (T3924), foetal bovine serum (FBS; 10270106), PBS (21-040-CVR), penicillin and streptomycin (SV30010) were obtained from Gibco (Thermo Fisher Scientific Inc., Waltham, MA, USA).

Preparation of sodium cantharidinate. Sodium cantharidinate. was dissolved in PBS ( $\mathrm{pH} 7.2)$ to prepare a stock solution at a concentration of $1.0 \mathrm{mmol} / 1$, which was stored at $-20^{\circ} \mathrm{C}$. Complete DMEM was added to dilute the sodium cantharidinate to the appropriate concentrations prior to use.

Patients and tissue specimens. A total of 62 patients, comprising 41 males and 21 females, with a mean age of 62.4 years (range, 34-78 years) were included in the present study. Human HCC tissue and tumor-surrounding tissue specimens were obtained by surgical resection at the Jilin University First Hospital (Changchun, China) between May 2012 and July 2013. The present study was approved by the Ethics Committee of Jilin University First Hospital and written informed consent was obtained from all patients. An experienced pathologist examined hematoxylin and eosin-stained sections from each tumor sample to confirm the histological diagnosis and assess the tumor content. Histological diagnoses, including the tumor differentiation and encapsulation, were made according to the guidelines proposed by the World Health Organization (34). The differentiation grade of the tumor and its clinical stage were recorded.
Immunohistochemical staining. Following deparaffinization, antigen retrieval and permeabilization, 5- $\mu \mathrm{m}$ slide-mounted liver tissue samples were subjected to immunostaining. The primary antibody used for immunostaining was mouse monoclonal antibody against S100A3 (Sigma-Aldrich; Merck Millipore). Briefly, following deparaffinization and rehydration, tissue sections were processed with antigen retrieval using 1X Trilogy (Biogenics, Napa, CA, USA) and diluted in $\mathrm{H}_{2} \mathrm{O}$ at room temperature. Slides were immersed in $3 \%$ $\mathrm{H}_{2} \mathrm{O}_{2}$ for $10 \mathrm{~min}$ and washed with PBS three times. Tissue sections were blocked with goat serum (Vestastain Elite ABC kit; Vector Laboratories, Burlingame, CA, USA) for $30 \mathrm{~min}$ at room temperature and the excess liquid discarded. Subsequently, slides were incubated with the primary S100A3 antibody (WH0006274M1, 1:1,000) for $60 \mathrm{~min}$ at $37^{\circ} \mathrm{C}$. Slides were then incubated with goat anti-mouse secondary antibody (1:500; C0158; Sigma-Aldrich; Merck Millipore) for $30 \mathrm{~min}$ at room temperature and washed with PBS 3-5 times. Diaminobenzidine (Dako Corp., Carpinteria, CA, USA) was subsequently used as the substrate for localizing antibody binding. Negative controls included serial sections from which either the primary or secondary antibody were excluded. The preparations were counterstained with hematoxylin, mounted with Permount (Merck Millipore, Darmstadt, Germany), examined by light microscopy (magnification, x100; Olympus CX31; Olympus Corp., Tokyo, Japan) and analyzed by ImagePro Plus 6.0 (Media Cybernetics, Inc., Rockville, MD, USA).

HepG2 cell culture and treatment. HepG2 cell lines were donated by the Jilin University Institute of Translational Medicine (Jilin, China). HepG2 cells were routinely cultured in complete DMEM supplemented with $50 \mathrm{U} / \mathrm{ml}$ penicillin and streptomycin and $10 \% \mathrm{FBS}$, in an atmosphere containing $5 \% \mathrm{CO}_{2}$ at $37^{\circ} \mathrm{C}$ in a cell incubator (HERAcell 150i; Thermo Fisher Scientific Inc.). Following trypsinization to passage the cells in T75 flasks for 3-5 days, the cells were counted using a blood count board in addition to trypan blue staining and reseeded in 96-well plates with a density of $5 \times 10^{4}$ cells $/ \mathrm{ml}$ in complete DMEM in the presence or absence of sodium cantharidinate $(5.0 \mu \mathrm{mol} / \mathrm{l})$. Analysis was performed via MTT assay or apoptosis detection, as outlined.

Isolation of primary human hepatocytes (PHH). All procedures were performed in accordance with the provision of the Ethical Commission of Jilin University First Hospital. PHH were obtained from healthy peritumoral liver resection specimens from non-hepatitis $B$ virus, non-hepatitis $C$ virus and non-human immunodeficiency virus-infected patients undergoing partial hepatectomy for primary HCC or secondary metastatic lesions caused by other types of cancer. PHH were isolated and cultured as described previously (35).

Effect of sodium cantharidinate on the viability of HepG2 cell lines. The inhibitory effect of sodium cantharidinate on the viability of HepG2 cells was detected by performing MTT assays, with all experimental steps performed according to the instructions of the kit. Cells were seeded on 96-well plates at a density of $5 \times 10^{4} / \mathrm{ml}$ at a volume of $200 \mu \mathrm{l}$ per well. All groups $(n=3)$, in the presence or absence of sodium 
cantharidinate $(0.2,1.0,5.0$ and $25.0 \mu \mathrm{mol} / \mathrm{l})$, were incubated for $24-72 \mathrm{~h}$. MTT $(1 \mathrm{mg} / \mathrm{ml})$ was added to each well, and the cells were for $4 \mathrm{~h}$ at $37 \mathrm{C}$. MTT solution was aspirated and $100 \mu \mathrm{l}$ DMSO was added. Subsequently, 96-well plates were analyzed using a microplate spectrophotometer (Synergy H1; BioTek Instruments, Inc., Winooski, VT, USA) at $540 \mathrm{~nm}$. Experiments were repeated in triplicate. The inhibition percentage was calculated as: Inhibition percentage $=(1-$ the value in experimental group/the value in the control group) $\mathrm{x} 100 \%$.

Flow cytometryfor measuring cell apoptosis. Annexin V-FITC and PI double staining flow cytometry analyses were employed. HepG2 cells were plated in 96-well plates containing $200 \mu \mathrm{l}$ medium, at a density of $5 \times 10^{4}$ cells/well. Induction of apoptosis in HepG2 cells was examined in the presence or absence of sodium cantharidinate $(5.0 \mu \mathrm{mol} / \mathrm{l})$. Following $48 \mathrm{~h}$ in culture, the cells were collected in $1.5 \mathrm{ml}$ centrifuge tubes, washed three times with cold PBS and binding buffer, and stained with Annexin V-FITC and PI (Annexin V-FITC Apoptosis Detection kit; BD Biosciences, San Jose, CA, USA) for apoptosis detection. HepG2 cells in centrifuge tubes were resuspended in binding buffer. FITC-Annexin V $(5 \mu \mathrm{l})$ was added to the tubes, which were incubated for $10 \mathrm{~min}$ at room temperature, followed by the addition of $5 \mu \mathrm{l}$ PI. Samples were incubated with PI for a further $15 \mathrm{~min}$ at room temperature and immediately analyzed using a flow cytometer (FACScan; BD Biosciences) using FlowJo FACS analysis software 7.6 (Tree Star, Inc., Ashland, OR, USA). Cells in different portions represented the different cell states as follows: Upper right, late-apoptotic cells; lower left, viable cells; lower right, early-apoptotic cells, upper left, dead cells.

Reverse transcription-quantitative polymerase chain reaction $(R T-q P C R)$. Total RNA was isolated from the HCC tissues and adjacent non-tumorous tissues or HepG2 cells using a Qiagen RNeasy Mini kit (Qiagen China Co., Ltd., Shanghai, China). Cultured HepG2 cells were scraped, lysed in Buffer RLT, and collected using cell scrapers (Thermo Fisher Scientific, Inc.). Human tissue samples were homogenized in Buffer RLT using pellet pestles (Sigma-Aldrich; Merck Millipore) and passed through a $27 \mathrm{G} \times 1 / 2$-inch needle. To remove lipid and tissue debris, the homogenates were centrifuged at $1,500 \mathrm{x} \mathrm{g}$ for $5 \mathrm{~min}$ at $4^{\circ} \mathrm{C}$, and the aqueous phase was collected. Following the RNeasy Mini kit instructions, 70\% ethanol was added to cell lysates or the homogenates and the samples were mixed by pipetting prior to being transferred to columns. Following centrifugation for $2 \mathrm{~min}$ at $4 \mathrm{C}$ and $12,000 \mathrm{x} \mathrm{g}$, the flow-through extract was retained and stored on ice. RNA quality was assessed with an Agilent 2100 Bioanalyzer (Agilent Technologies GmbH, Waldbronn, Germany). cDNA was synthesized with Supermix II reverse transcriptase using random hexamer primers (TransGen Biotech, Beijing, China) according to the manufacturer's instructions. Primers for S100A3 and GAPDH were designed and synthesized by Shanghai Sangon Biological Engineering Co., Ltd. (Shanghai, China). An Applied Biosystems StepOnePlus Real-Time PCR system (Thermo Fisher Scientific Inc.) was used to determine the mRNA levels of S100A3 and GAPDH (internal control). Primers were designed as follows: S100A3, forward 5'-GAC
Table I. Clinicopathological features of patients with hepatocellular carcinoma $(n=62)$.

\begin{tabular}{lcc}
\hline Variable & $\begin{array}{c}\text { Male } \\
(\mathrm{n}=41)\end{array}$ & $\begin{array}{c}\text { Female } \\
(\mathrm{n}=21)\end{array}$ \\
\hline $\begin{array}{lc}\text { Age, years (\%) } \\
\text { Mean }\end{array}$ & 54.6 & 68.8 \\
Range & $34-76$ & $51-78$ \\
Minimum & $34(2.4)$ & $51(9.5)$ \\
$\quad$ Maximum & $76(4.8)$ & $78(14.3)$ \\
Grade of differentiation, $\mathrm{n}(\%)$ & & \\
$\quad$ Poorly differentiated & $20(48.8)$ & $12(57.1)$ \\
$\quad$ Moderately differentiated & $12(29.3)$ & $4(19.1)$ \\
$\quad$ Highly differentiated & $9(21.9)$ & $5(23.8)$ \\
Clinical stage, $\mathrm{n}(\%)$ & & \\
I/II & $14(34.1)$ & $7(33.3)$ \\
III/IV & $27(65.9)$ & $14(66.7)$ \\
\hline
\end{tabular}

CATCTGGTTCAGGTTCC-3' and reverse 5'-ACATTCCC GAAACTCAGTCG-3'; and GAPDH, forward 5'-CCAGGTG GTCTCCTCTGACTT-3' and reverse 5'-GTTGCTGTAGCC AAATTCGTTGT-3'. PCR products were $200 \mathrm{bp}$ in length.

Western blotting. HepG2 and PHH cells were lysated and quantitated using a Boster protein quantitative kit (AR1110; Wuhan Boster Biological Technology, Ltd., Wuhan, China). Subsequently, $50 \mu \mathrm{g}$ protein were prepared in SDS sample buffer (62.5 mM Tris-HCl [pH 6.8], 2\% SDS, $10 \%$ glycerol, $50 \mathrm{mM}$ DTT and $0.1 \%$ bromophenol blue) with a mixture of protease inhibitors and PhosSTOP Phosphatase Inhibitor (Roche Diagnostics, Basel, Switzerland). Proteins were separated by $10 \%$ SDS-PAGE and transferred to a nitrocellulose membrane (Roche Diagnostics). The membrane was blocked with $0.05 \%$ Tween-20 in PBS containing 5\% skimmed milk and incubated overnight with the primary S100A3 antibody (WH0006274M1; 1:1,000; Sino Biological Inc., Beijing, China) at $4^{\circ} \mathrm{C}$ overnight. The membrane was subsequently washed three times in $0.05 \%$ Tween 20 in PBS and incubated with a horseradish peroxdiase-conjugated goat anti-rabbit secondary antibody (SA00001-2; 1:1,000; Proteintech Group, Inc., Wuhan, China) for $2 \mathrm{~h}$ at room temperature. Following washing, protein bands were visualized using an enhanced chemiluminescent system (Thermo Fisher Scientific, Inc.). The image analysis was conducted using Image $\mathbf{J}$ software $1.48 \mathrm{u}$ (National Institute of Health, NY, USA). $\beta$-actin antibody $(4967 ; 1: 1,000)$ was obtained from Cell Signaling Technology, Inc. (Danvers, MA, USA).

Statistical analysis. All data were analyzed and assessed for significance using the Pearson omnibus normality test. All data are presented as the mean \pm standard deviation. Mean values were compared using paired $t$-tests (two groups), followed by the Bonferroni correction for multiple comparison tests. $\mathrm{P}<0.05$ was considered to indicate a statistically significant difference. All statistical tests were performed using Prism software (GraphPad Software 5.0, Inc., La Jolla, CA, USA). 
A

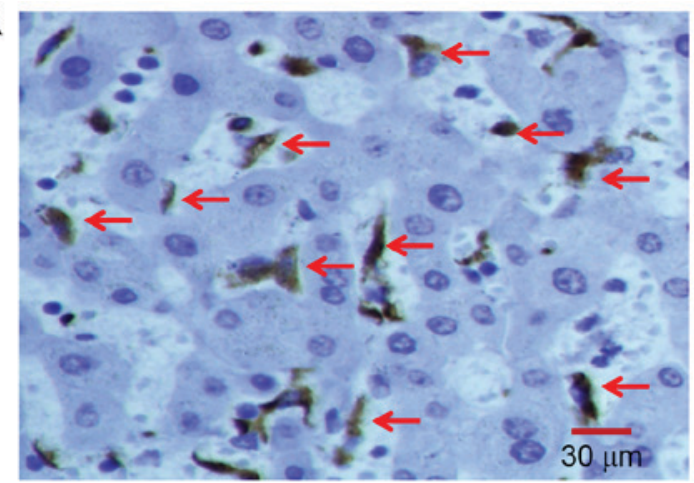

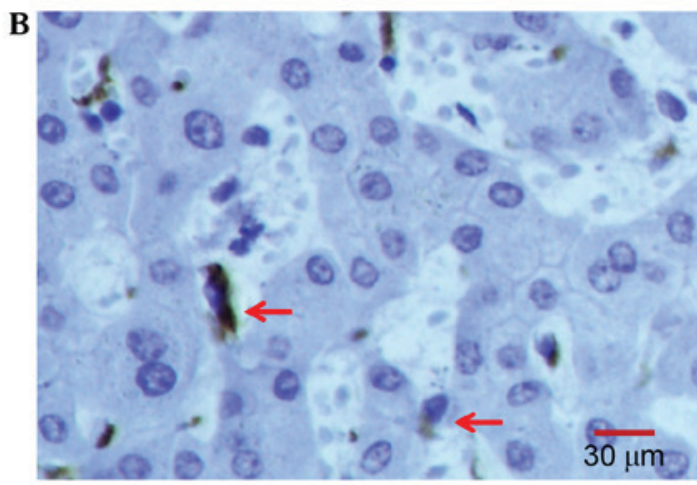

$\mathbf{E}$

S100A3

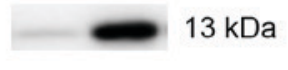

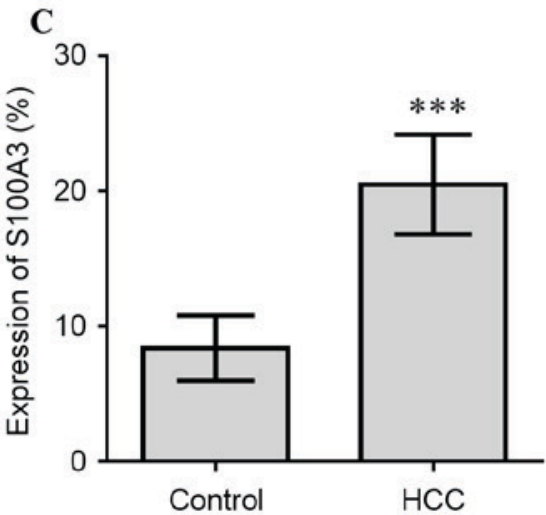

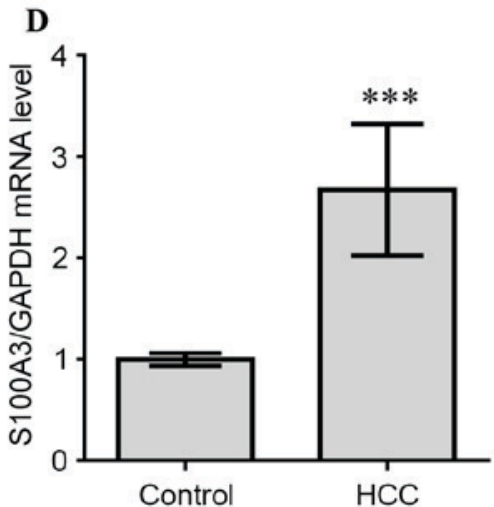

$\beta$-actin

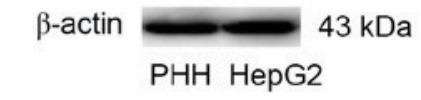

Figure 1. Expression of S100A3 in human HCC tissues and HepG2 cells. (A) Immunohistochemical staining of S100A3 in human HCC tissues and (B) adjacent non-tumorous tissues, the red arrows indicate the S100A3-positive cells. S100A3 (C) protein and (D) mRNA expression levels in human adjacent non-tumorous tissue (control) compared with human HCC tissues (HCC), respectively. (E) Western blotting indicated the expression of S100A3 expressed in HepG2 cells and PHH. Data are expressed as the mean \pm standard deviation of three experiments $\left({ }^{* * *} \mathrm{P}<0.001\right.$ vs. control). HCC, hepatocellular carcinoma; S100A3, S100 calcium-binding protein A3; $\mathrm{PHH}$, primary human hepatocytes.

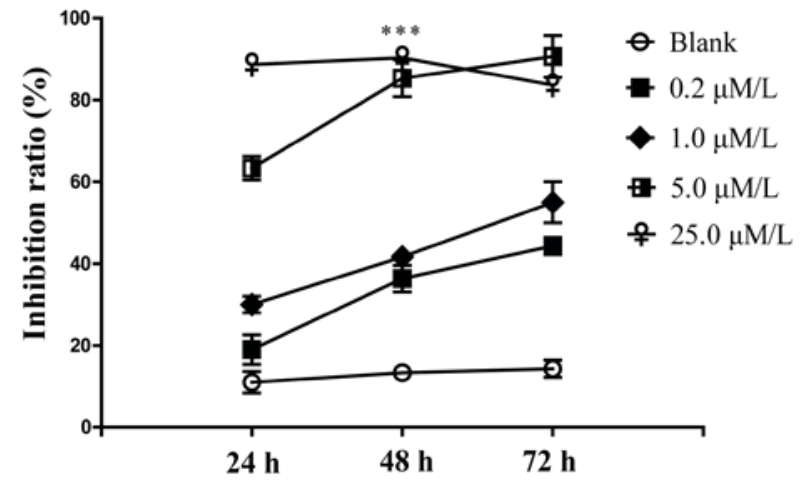

Figure 2. Treatment with sodium canthardinate inhibits the viability of HepG2 cells. HepG2 cells were cultured in complete Dulbecco's modified Eagle medium. The MTT assay revealed that sodium cantharidinate significantly inhibited the viability of HepG2 cells ( ${ }^{* * *} \mathrm{P}<0.001$ vs. blank). The inhibitory effects of sodium cantharidinate on HepG2 were dose- and time-dependent within the ranges of 0.2-5.0 $\mu \mathrm{mol} / 1$ and 24-72 h. Blank, Dulbecco's modified Eagle medium alone.

\section{Results}

Clinicopathological features of patients. Experimental samples were obtained from patients who underwent surgical resection of human $\mathrm{HCC}$ with a range of grade differentiations. Expression levels of S100A3 in HCC tissues and adjacent non-tumorous tissues were recorded and analyzed.
The demographics of the patients are shown in Table I, along with the clinical stages of the HCC and the grades of differentiation. There was an incidence of $34.1 \%$ for stage I/II and $65.9 \%$ for stage III/IV, respectively, in males. In females, the incidence of stage I/II was $33.3 \%$, and stage III/IV was $66.7 \%$, respectively. The incidence of grade differentiation was also recorded in patients. Poor differentiation was predominantly detected in patients, with incidence rates of $48.8 \%$ in males and $57.1 \%$ in females.

Expression of S100A3 in human HCC tissues and HepG2 cells. Immunohistochemical staining was performed to assess the protein expression of S100A3 in human HCC tissues and adjacent non-tumorous tissues. The results indicated that S100A3 was expressed in the cytoplasm of HCC tissues and adjacent non-tumorous tissues of the patients with HCC (Fig. 1A and B, respectively). The expression of S100A3 significantly increased in the HCC tissues $(\mathrm{P}<0.001$; Fig. $1 C)$, with expression predominantly detected in the tumor regions. The mean percentage of S100A3 in adjacent non-tumorous tissues and HCC tissues was 8 and $22 \%$, respectively. The difference was significant $(\mathrm{P}<0.001$; Fig. 1C). Total RNA (mRNA) was extracted from HCC tissues and adjacent non-tumorous tissues. qPCR was used to detect the expression of S100A3 mRNA. There was a significant difference between the S100A3 mRNA levels in the HCC and the adjacent non-tumorous tissues $(\mathrm{P}<0.001$; Fig. 1D). These results were 
A

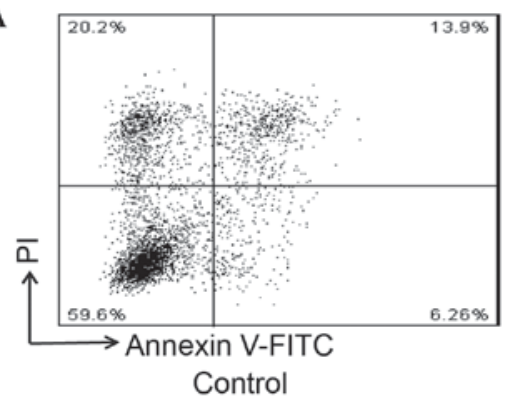

C

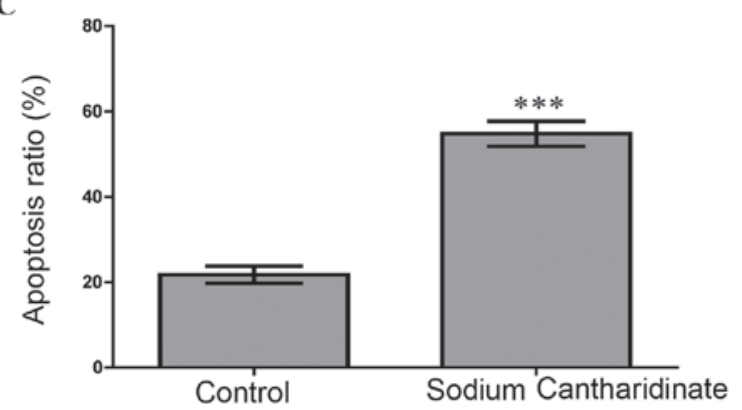

B

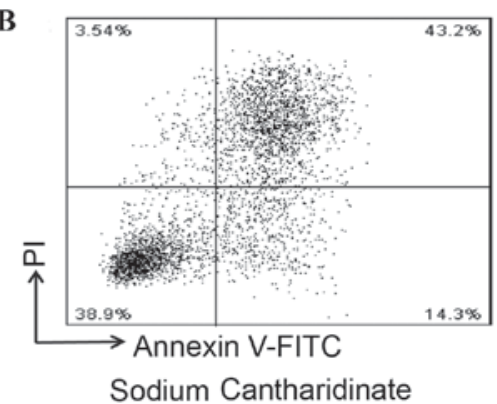

Figure 3. Apoptosis detection using flow cytometry of HepG2 cells in the presence or absence of sodium cantharidinate. Flow cytometric analysis of apoptosis in HepG2 cells treated with sodium cantharidinate. Cells were exposed to either (A) control solution (0.1\% DMSO in medium) or (B) sodium cantharidinate at $5.0 \mu \mathrm{M} / 1$ and incubated for $48 \mathrm{~h}$. Experiments were repeated at least three times. (C) Percentage of apoptotic cells. Apoptotic cells were calculated as the percentage of apoptotic cells in the upper right portion and the lower right portion relative to the total number of the cells. Data are expressed as the mean \pm standard deviation of three experiments $\left({ }^{* * *} \mathrm{P}<0.001 \mathrm{vs}\right.$. control). DMSO, dimethylsulfoxide; PI, propidium iodide; FITC, Fluorescein isothiocyanate.

A

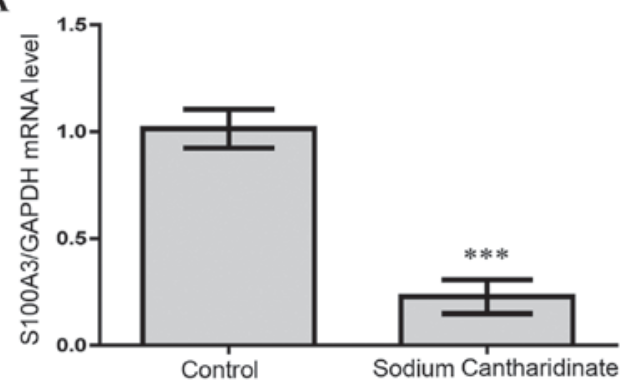

B

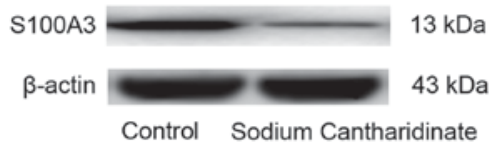

C

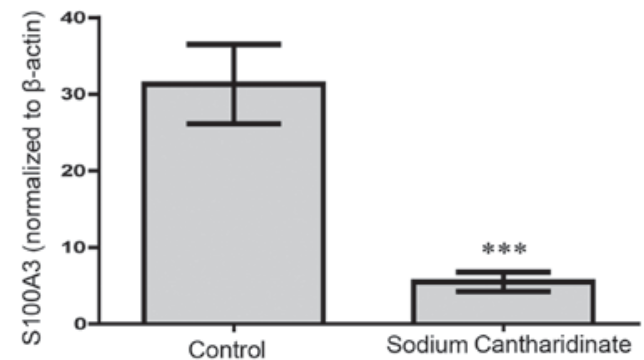

Figure 4. Effect of sodium cantharidinate on the expression of S100A3 in HepG2 cells. (A) S100A3 gene alteration of sodium cantharidinate-treated HepG2 cells compared with the control. (B and C) Western blotting was performed to indicate S100A3 protein expression levels in HepG2 cells. HepG2 cells were exposed to either control solution ( $0.1 \%$ DMSO in medium) or sodium cantharidinate $(5.0 \mu \mathrm{M} / \mathrm{l})$ and incubated for $48 \mathrm{~h}$. Experiments were performed in triplicate. Data are expressed as the mean \pm standard deviation of three experiments $\left({ }^{* * * *} \mathrm{P}<0.001\right.$ vs. control). S100A3, S100 calcium-binding protein A3. consistent with the findings of immunohistochemical staining. The HepG2 cell line is a specific human HCC cell line that has often been used for mechanism studies in vitro (36). S100A3 expression in HepG2 cells was also investigated by western blotting. Fig. 1E indicated S100A3 expression was higher in HepG2 cells, as compared with PHH.

Effect of sodium cantharidinate on the viability of HepG2 cells. HepG2 cells were cultured in complete DMEM. The MTT assay revealed that sodium cantharidinate significantly inhibited the viability of HepG2 cells $(\mathrm{P}<0.001)$. The inhibitory effects of sodium cantharidinate on HepG2 were dose- and time-dependent within the ranges of 0.2-5.0 $\mu \mathrm{mol} / 1$ and 24-72 h. Treatment with sodium cantharidinate at $5.0 \mu \mathrm{mol} / 1$ for $48 \mathrm{~h}$ elicited the greatest inhibitory effect. This dose inhibited the viability of HepG2 cells with an inhibitory rate exceeding $90 \%$, compared with that of the blank control group $(\mathrm{P}<0.001)$. The time-effect curve is illustrated in Fig. 2.

Annexin V-FITC assay. An Annexin V-FITC and PI double staining assay was performed to explore whether sodium cantharidinate induced HepG2 cell apoptosis. HepG2 cells were treated with sodium cantharidinate at a concentration of $5.0 \mu \mathrm{mol} / \mathrm{l}$ for $48 \mathrm{~h}$ and were analyzed using flow cytometry. When compared with the control group (Fig. 3A), the numbers of early and late apoptotic cells markedly increased in the sodium cantharidinate-treated group (Fig. 3B). Statistical analysis demonstrated that the proportion of early and late apoptotic cells in the sodium cantharidinate-treated group reached $57.2 \%$, which was significantly greater than the proportion observed in the control group $(20.1 \%)(\mathrm{P}<0.001$; Fig. 3C). This finding indicated that sodium cantharidinate significantly induced the apoptosis of HepG2 cells. 
Effect of sodium cantharidinate on the expression of S100A3 in HepG2 cells. HepG2 cell pellets were harvested for the detection of S100A3 gene and protein expression $48 \mathrm{~h}$ after incubation in the presence or absence of sodium cantharidinate $(5.0 \mu \mathrm{mol} / \mathrm{l})$. Fig. $4 \mathrm{~A}$ indicates that the expression of S100A3 mRNA in the sodium cantharidinate-treated group significantly decreased (0.22-fold) when compared with the control group $(\mathrm{P}<0.001)$. The relative expression of S100A3 protein in HepG2 cells was investigated by western blotting (Fig. 4B). HepG2 cells expressed a large quantity of S100A3; however, a 6-fold decrease in protein expression was observed (normalized to $\beta$-actin) after treatment with $5.0 \mu \mathrm{mol} / 1$ sodium cantharidinate (Fig. 4C). Consistent with the q-PCR results, these findings demonstrated that sodium cantharidinate inhibited the mRNA and protein expression levels of S100A3. These results suggested that sodium cantharidinate may be able to inhibit the expression of S100A3 and therefore may have the ability to block tumor growth.

\section{Discussion}

Globally, HCC is a leading cause of cancer-related mortality, with incident rates still on the increase and an annual mortality rate of $\sim 800,000$ (1). Although advances in surgical procedures, including hepatic resection and liver transplantation, have aided the treatment of HCC, patient prognosis has only marginally improved and the frequency of recurrence is considerably high, even after liver transplantation (37). The pathogenesis of HCC remains unclear; however, it has generally become accepted that the genetic mutations that occur within normal cells are associated with carcinogenic risk factors, including environmental factors, smoking, frequent consumption of raw freshwater fish, hepatitis B virus infection and a family history of HCC (38). Treatments that target mutant genes are of clinical significance. S100A3, which is a structurally and functionally associated protein, is widely distributed in multiple tumor types (39). It has been indicated that dysregulated expression and function of S100A3 contributes to pathological conditions, including cancer metastasis and diseases associated with defective assembly (15).

It has previously been unclear whether S100A3 has an important role in HCC. The present study showed that mRNA and protein expression levels of S100A3 were significantly increased in HCC and that S100A3 expression in human HCC was significantly inhibited by sodium cantharidinate. Effective anti-cancer agents exhibit the desirable feature of potent cytotoxicity towards tumor cells while eliciting limited adverse effects on normal cells (40). Sodium cantharidinate may directly destroy the liver cancer cell lines, which provided the favorable theoretical basis for the application of treatment of primary liver cancer (41). The present study demonstrated that sodium cantharidinate exhibited inhibitory activity against S100A3 in human HCC. Sodium cantharidinate was able to inhibit the proliferation of HepG2 cells within the ranges of 0.2-5.0 $\mu \mathrm{mol} / 1$ and 24-72 $\mathrm{h}$. Furthermore, sodium cantharidinate reduced the mRNA and protein expression levels of S100A3 in human HepG2 cells and significantly induced apoptosis in HepG2 cells. To the best of our knowledge, this is the first study that has shown that mRNA and protein expression levels of S100A3 are downregulated by sodium cantharidinate.

In conclusion, the present study indicated S100A3 has an important role in human HCC occurrence and development. Sodium cantharidinate has the therapeutic ability to inhibit the expression of S100A3 in HepG2 cells and induce cellular apoptosis. The present study provides the theoretical basis for the application of sodium cantharidinate in the treatment of primary liver cancer.

This study did not receive any specific grant from funding agencies in the public, commercial, or not-for-profit sectors.

\section{Acknowledgements}

This study was supported in part by grants from the Jilin Provincial Natural Science Foundation of China (grant no. 20140520014JH) and the Fourth Young Scientist Fund of Jilin University (grant no. 2013068).

\section{References}

1. Llovet JM, Burroughs A and Bruix J: Hepatocellular carcinoma. Lancet 362: 1907-1917, 2003.

2. Shirabe K, Kanematsu T, Matsumata T, Adachi E, Akazawa K and Sugimachi K: Factors linked to early recurrence of small hepatocellular carcinoma after hepatectomy: Univariate and multivariate analyses. Hepatology 14: 802-805, 1991.

3. Yamashita Y, Morita K, Iguchi T, Tsujita E, Soejima Y, Taketomi A and Maehara Y: Surgical impacts of an en bloc resection of the diaphragm for hepatocellular carcinoma with gross diaphragmatic involvement. Surg Today 41: 101-106, 2011.

4. Sakaguchi T, Suzuki S, Morita Y, Oishi K, Suzuki A,Fukumoto K, Inaba K, Nakamura $\mathrm{S}$ and Konno H: Impact of the preoperative des-gamma-carboxy prothrombin level on prognosis after hepatectomy for hepatocellular carcinoma meeting the milan criteria. Surg Today 40: 638-645, 2010.

5. Taketomi A, Fukuhara T, Morita K, Kayashima H, Ninomiya M, Yamashita Y, Ikegami T, Uchiyama H, Yoshizumi T, Soejima Y, et al: Improved results of a surgical resection for the recurrence of hepatocellular carcinoma after living donor liver transplantation. Ann Surg Oncol 17: 2283-2289, 2010.

6. Nault JC, De Reyniès A, Villanueva A, Calderaro J, Rebouissou S, Couchy G, Decaens T, Franco D, Imbeaud S, Rousseau F, et al: A hepatocellular carcinoma 5-gene score associated with survival of patients after liver resection. Gastroenterology 145: 176-187, 2013.

7. Balkwill $\mathrm{F}$ and Mantovani A: Inflammation and cancer: Back to Virchow? Lancet 357: 539-545, 2010.

8. de Visser KE, Eichten A and Coussens LM: Paradoxical roles of the immune system during cancer development. Nat Rev Cancer 6: 24-37, 2006.

9. Posner MR: Paradigm shift in the treatment of head and neck cancer: The role of neoadjuvant chemotherapy. Oncologist 10 (Suppl 3): S11-S19, 2005.

10. Bruix J, Gores GJ and Mazzaferro V: Hepatocellular carcinoma: Clinical frontiers and perspectives. Gut 63: 844-855, 2014.

11. Kaseb AO, Abaza YM and Roses RE: Multidisciplinary management of hepatocellular carcinoma. Recent Results Cancer Res 190: 247-259, 2013.

12. Fritz G, Mittl PR, Vasak M, Grutter MG and Heizmann CW: The crystal structure of metal-free human EF-hand protein S100A3 at 1.7-A resolution. J Biol Chem 277: 33092-33098, 2002.

13. Kizawa K, Takahara H, Unno M and Heizmann CW: S100 and S100 fused-type protein families in epidermal maturation with special focus on S100A3 in mammalian hair cuticles. Biochimie 93: 2038-2047, 2011.

14. Kizawa K, Inoue T, Yamaguchi M, Kleinert P, Troxler H, Heizmann CW and Iwamoto Y: Dissimilar effect of perming and bleaching treatments on cuticles: Advanced hair damage model based on elution and oxidation of S100A3 protein. J Cosmet Sci 56: 219-226, 2005. 
15. Kizawa K, Unno M, Takahara H and Heizmann CW: Purification and characterization of the human cysteine-rich S100A3 protein and its pseudo citrullinated forms expressed in insect cells. Methods Mol Biol 963: 73-86, 2013

16. Kizawa $K$, Jinbo Y, Inoue $T$, Takahara H, Unno M, Heizmann CW and Izumi Y: Human S100A3 tetramerization propagates $\mathrm{Ca}(2+) / \mathrm{Zn}(2+)$ binding states. Biochim Biophys Acta 1833: $1712-1719,2013$.

17. Wright NT, Cannon BR, Wilder PT, Morgan MT, Varney KM, Zimmer DB and Weber DJ: Solution structure of S100A1 bound to the CapZ peptide (TRTK12). J Mol Biol 386: 1265-1277, 2009.

18. Markowitz J, Rustandi RR, Varney KM, Wilder PT, Udan R, Wu SL, Horrocks WD and Weber DJ: Calcium-binding properties of wild-type and EF-hand mutants of S100B in the presence and absence of a peptide derived from the C-terminal negative regulatory domain of p53. Biochemistry 44: 7305-7314, 2005.

19. Malashkevich VN, Varney KM, Garrett SC, Wilder PT, Knight D, Charpentier TH, Ramagopal UA, Almo SC, Weber DJ and Bresnick AR: Structure of Ca2+-bound S100A4 and its interaction with peptides derived from nonmuscle myosin-IIA. Biochemistry 47: 5111-5126, 2008.

20. Attallah AM, Omran MM, Attallah AA, Abdallah SO, Farid K, Darwish H, El-Dosoky I and Shaker YM: HCC-ART score, a simple, highly sensitive and specific test for early diagnosis of hepatocellular carcinoma: A large-scale, multicentre study. Br J Cancer 109: 1657-1665, 2013.

21. Motawi TK, Shaker OG, El-Maraghy SA and Senousy MA: Serum micrornas as potential biomarkers for early diagnosis of hepatitis $C$ virus-related hepatocellular carcinoma in egyptian patients. PLoS One 10: e0137706, 2015.

22. Hu B, Wang SS and Du Q: Traditional Chinese medicine for prevention and treatment of hepatocarcinoma: From bench to bedside. World J Hepatol 7: 1209-1232, 2015.

23. Li M, Qiao C, Qin L, Zhang J and Ling C: Application of traditional Chinese medicine injection in treatment of primary liver cancer: A review. J Tradit Chin Med 32: 299-307, 2012.

24. Wu P, Dugoua JJ, Eyawo O and Mills EJ: Traditional Chinese Medicines in the treatment of hepatocellular cancers: A systematic review and meta-analysis. J Exp Clin Cancer Res 28: 112, 2009.

25. Deng LP, Dong J, Cai H and Wang W: Cantharidin as an antitumor agent: A retrospective review. Curr Med Chem 20: 159-166, 2013

26. Huang YP, Ni CH, Lu CC, Chiang JH, Yang JS, Ko YC, Lin JP, Kuo JH, Chang SJ and Chung JG: Suppressions of migration and invasion by cantharidin in TSGH-8301 human bladder carcinoma cells through the inhibitions of matrix metalloproteinase-2/-9 signaling. Evid Based Complement Alternat Med 2013: 190281, 2013.

27. Li W, Xie L, Chen Z, Zhu Y, Sun Y, Miao Y, Xu Z and Han X: Cantharidin, a potent and selective PP2A inhibitor, induces an oxidative stress-independent growth inhibition of pancreatic cancer cells through G2/M cell-cycle arrest and apoptosis Cancer Sci 101: 1226-1233, 2010.

28. Zhan YP, Huang XE, Cao J, Lu YY, Wu XY, Liu J, Xu X, Xu L, Xiang J and Ye LH: Clinical study on safety and efficacy of Qinin ${ }^{\circledR}$ (cantharidin sodium) injection combined with chemotherapy in treating patients with gastric cancer. Asian Pac J Cancer Prev 13: 4773-4776, 2012.
29. Kim YM, Ku MJ, Son YJ, Yun JM, Kim SH and Lee SY: Anti-metastatic effect of cantharidin in A549 human lung cancer cells. Arch Pharm Res 36: 479-484, 2013.

30. Yeh CH, Yang YY, Huang YF, Chow KC and Chen MF: Induction of apoptosis in human Hep3B hepatoma cells by norcantharidin through a p53 independent pathway via TRAIL/DR5 signal transduction. Chin J Integr Med 18: 676-682, 2012.

31. Kim JA, Kim Y, Kwon BM and Han DC: The natural compound cantharidin induces cancer cell death through inhibition of heat shock protein 70 (HSP70) and Bcl-2-associated athanogene domain 3 (BAG3) expression by blocking heat shock factor 1 (HSF1) binding to promoters. J Biol Chem 288: 28713-28726, 2013.

32. Wen SQ, Chen Q and Hu M: Experimental study on the inhibitory effect of sodium cantharidinate on human hepatoma Hepg 2 cells. Afr J Tradit Complement Altern Med 11: 131-134, 2013.

33. Liu B, Sun WY, Zhi CY, Lu TC, Gao HM, Zhou JH, Yan WQ and Gao HC: Role of S100A3 in human colorectal cancer and the anticancer effect of cantharidinate. Exp Ther Med 6: 1499-1503, 2013.

34. Tateishi Y, Furuya M, Kondo F, Torii I, Nojiri K, Tanaka Y, Umeda S, Okudela K, Inayama Y, Endo I and Ohashi K: Hepatocyte nuclear factor-1 $\alpha$ inactivated hepatocellular adenomas in patient with congenital absence of the portal vein: A case report. Pathol Int 63: 358-363, 2013.

35. Yang D, Liu N, Zuo C, Lei S, Wu X, Zhou F, Liu C and Zhu H: Innate host response in primary human hepatocytes with hepatitis $\mathrm{C}$ virus infection. PLoS ONE 6: e27552, 2011.

36. Zhou XN, Li GM, Xu YC, Zhao TJ and Wu JX: Knockdown of decoy receptor 3 impairs growth and invasiveness of hepatocellular carcinoma cell line of HepG2. Chin Med J (Engl) 129: 2623-2629, 2016

37. Sharma P, Welch K, Hussain H, Pelletier SJ, Fontana RJ, Marrero J and Merion RM: Incidence and risk factors of hepatocellular carcinoma recurrence after liver transplantation in the MELD era. Dig Dis Sci 57: 806-812, 2012.

38. Chen JH, Wang YY, Lv WB, Gan Y, Chang W, Tian NN, Huang XH, Liu L, Yu XF and Chen SD: Effects of interactions between environmental factors and KIF1B genetic variants on the risk of hepatocellular carcinoma in a Chinese cohort. World J Gastroenterol 22: 4183-4190, 2016.

39. Kang M, Lee HS, Lee YJ, Choi WS, Park YH, Jeong CW, Ku JH, Kim HH and Kwak C: S100A3 suppression inhibits in vitro and in vivo tumor growth and invasion of human castration-resistant prostate cancer cells 85: 273.e9-15, 2015.

40. Srivastava V and Lee H: Chloroquine-based hybrid molecules as promising novel chemotherapeutic agents. Eur J Pharmacol 762: 472-486, 2015

41. Yeh CB, Su CJ, Hwang JM and Chou MC: Therapeutic effects of cantharidin analogues without bridging ether oxygen on human hepatocellular carcinoma cells. Eur J Med Chem 45: 3981-3985, 2010 . 